\title{
Determination of Active Protection Measures against Fire in Wuse Market of the Federal Capital Territory of Nigeria
}

\author{
Odaudu Ugbede Sunday ${ }^{*}$, S.N. Zubairu, A.D. Isah \\ Department of Architecture, Federal University of Technology, Minna, Nigeria \\ *Corresponding author: arcodauduugbede@yahoo.com
}

Received February 07, 2019; Revised March 14, 2019; Accepted March 22, 2019

\begin{abstract}
Fire outbreak is the leading cause of lives and properties loss in Nigerian markets. In order to reduce this problem, a study was conducted on Wuse market of the Federal Capital Territory of Nigeria with the aim of determining the active protection measures against fire in the market, in order to generate guidelines that can reduce the occurrences of fire outbreaks in Nigerian markets. Systematic sampling method was applied at every $5^{\text {th }}$ interval of sales points for the purpose of getting the sample size for this study; this led to the selection of 419 sales points out of the 2,091 sales points in the market. The instruments that were used to collect the primary research data are questionnaires, focus group discussions, interview questions, discussions and direct observation schedule. The secondary research data were obtained from the reviews of the relevant literature on fire outbreaks in markets and other public buildings; other fire related issues in and outside Nigeria. Among the research findings are: the use of substandard fire extinguishers causes rapid spread of fires in the market; there are buildings in the market without front verandahs or corridors for mounting fire protection devices on their walls. Among the recommended guidelines are: the government of Nigeria should ban the use of substandard fire extinguishers in markets; floors of the lock-up shops in markets must be designed to have front verandahs/corridors and their inner walls should be appropriately used as the locations where the required wall mountable fire protection devices shall be fixed upon.
\end{abstract}

Keywords: fire outbreaks, guidelines, markets, Nigeria, protection

Cite This Article: Odaudu Ugbede Sunday, S.N. Zubairu, and A.D. Isah, "Determination of Active Protection Measures against Fire in Wuse Market of the Federal Capital Territory of Nigeria." American Journal of Civil Engineering and Architecture, vol. 7, no. 2 (2019): 61-66. doi: 10.12691/ajcea-7-2-3.

\section{Introduction}

Markets are public places where people meet for business transactions; they are where almost all the basic needs of people are sold in retails and wholesales [1,2]. The importance of markets cannot be over emphasised. They contribute to the generation of local revenue, create employment, provide household incomes and support human resource development by providing for and educating the children or other family relatives of the sales people $[3,4]$. Therefore, active protection measures against fire in markets is very important for the sales people and other users of markets, especially in Nigeria where there are cases of fire outbreaks.

In this context, active protection measures against fire is the readiness to fight fire with the fire protection devices when it breaks out in markets. Protection measure against fire is an important element in disaster risk reduction and it encompasses adequate awareness and readiness to render appropriate responses [5]. However, less has been done globally to improve the levels of protection measures for disasters [6]. Protection measures for disasters such as fire outbreaks can be enhanced by educating people and improving the preventive mechanisms [7]. There are technological advancements in fire safety for commercial and industrial facilities worldwide [8]. However, fire outbreak in Nigerian markets is a recurring problem [9]. It remains the leading cause of lives and properties loss in Nigerian markets.

To this end, this research aimed to determine the active protection measures against fire in Wuse market of the Federal Capital Territory (FCT) of Nigeria, in order to generate guidelines that can reduce the occurrences of fire outbreaks in markets in Nigeria. Objectives of the study are: to evaluate the adequacy of fire protection devices in Wuse market; to ascertain the maintenance frequencies of fire protection devices in Wuse market; to find out the number of sales people that know how to operate fire protection devices, and to assess the effectiveness of the firefighting personnel in Wuse market.

The reason for selecting the FCT of Nigeria as the study area is because of the frequent fire outbreaks in markets in the territory. For example, there was fire outbreak in Wuse market in the FCT of Nigeria on 17th January, 2003 [10]. Also, there was fire outbreak in Garki model market in the FCT of Nigeria on 30th December, 2015 [11]. The scope of this study is the whole buildings in Wuse market. 
According to Reference [12], Wuse market is located along Herbert Macaulay Street, Old Wuse (off Premium Times, Wuse 1) in the Abuja Municipal Area Council of the FCT of Nigeria. FCT of Nigeria is the capital city of Nigeria which is located in the central Nigeria [13].

\section{Methods and Procedures}

Descriptive survey method was used for this study which led to the generation of quantitative and qualitative data. There are seven regional built-up markets under the control of FCT Markets Management Committee in the Federal Capital Development Authority of Nigeria [14]. Having selected the Federal Capital Territory (FCT) of Nigeria as the study area, Wuse market was subsequently and purposively selected for this study because it has experienced fire outbreak. Also, it is the largest market in the FCT of Nigeria [15]. Thus, it became important that this largest market that has experienced fire outbreak is study, so that lessons can be learnt from it.

The five instruments that were used to collect the primary research data are questionnaires, focus group discussions, interview questions, discussions and direct observation schedule. According to the managing company of Wuse market [15], there are 1,365 lock-up shops in the old block and 220 lock-up shops in the new block of the market, making it a total number of 1,585 lock-up shops. Also, there are 500 open stalls and six detached restaurants in the market. Thus, by summing up the numbers of the lock-up shops, open stalls and the detached restaurants in the market, it mathematically implies that there are 2,091 sales points in Wuse market. $20 \%$ sample size of the target population of the study is a good recommended sample size $[16,17,18]$.

Hence, systematic sampling method was applied at every $5^{\text {th }}$ interval of sales points for the purpose of getting the sample size for this study; this led to the selection of 419 sales points out of the total number of sales points in the market. The 419 sales points selected for this study are slightly above $20 \%$ of the total number of sales points in the market and this in turn has made the sample size to be acceptable. In this case, questionnaires were administered to 419 sales people in the selected sales points with the help of five research assistants. This means that in each sales point, a questionnaire was administered to one sales person.

The outstanding benefits of using the method of focus group in a research is acquired in smaller groups of four or five participants $[19,20]$. Thus, focus group discussion were organised for the various categories of sales people in the market with the help of five research assistants that made it easier for the researchers to participate less in this aspect. In this research, focus group discussions that were made up of five sales people in 30 different groups were organised in the market. The reason for using up to 30 numbers of different focus groups in the market is to adequately and efficiently maximise the outstanding benefits of the research instrument or to get the maximum results from large numbers of the participants with respect to the size of the market in terms of the number of sales points (2,091 sales points).

In addition, interview questions were administered to the private and government organisations (Markets
Operating Bodies) that are relevant to this research. Private organisations are the managing company of the markets and the National Association of Nigerian Traders (NANT) of the FCT of Nigeria. The only government organisation is the Federal Fire Service of Nigeria (FFSN) in the Federal Capital Territory (FCT) of Nigeria. A set of interview questions were administered to each of these organisations for the management board meetings to be called with regards to them, so that the members of the management board of organisations can interact for generalised answers to the interview questions. Likewise, discussions were made with the staff of the FCT Market Operating Bodies in conjunction with direct observations for the purpose of this study. The secondary data were obtained from the reviews of the relevant literature on fire outbreaks in markets and other public buildings; other fire related issues in and outside Nigeria.

\section{Results and Discussion}

In this section, results and discussion are categorised into two. The first category is the data from the FCT markets operating bodies such as the FFSN, NANT and the managing company of the market in conjunction with the data from observations. The second category is the data from the sales people.

\subsection{Data from the FCT Markets Operating Bodies in Conjunction with Observations}

In this subsection, active protection measures against fire were determined with respect to the issues associated with the firefighting equipment in the market based on the data from the FCT Markets Operating Bodies in conjunction with observations. Table 1 shows the distribution of the issues associated with firefighting equipment in the market with their number of observations, and common locations. It also shows that the issues associated with the firefighting equipment are common in the new and old sections of the market.

Fire protection devices are to be frequently maintained in an operable condition. According to Reference [21], fire extinguishers shall be subjected to maintenance at the intervals of not more than one year. References [22] and [23] added that the visual inspection interval of fire protection devices should be on monthly bases, and their basic service or maintenance intervals should be on annual bases.

Contrary to these immediate statements with regards to the maintenance intervals of fire protection devices, the interview questions administered to the Federal Fire Service of Nigeria (FFSN) indicated that fire protection devices in Wuse market are not properly maintained. According to the discussion with the management staff of the market, they are only maintained after use. This implies that they are never maintained at all, unless there is fire outbreak that will lead to their maintenance after use. It also implies that if there is no fire outbreak in the market for a very long period of time like two years and above, no maintenance work will be executed on them; this affirmed that the fire protection devices in Wuse market are not properly maintained as responded by the FFSN in the interview questions. 
Table 1. Distribution of the Issues Associated with Fire Fighting Equipment in Wuse Market

\begin{tabular}{|c|c|c|}
\hline $\mathrm{S} / \mathrm{N}$ & ISSUE ASSOCIATED WITH FIRE FIGTHING EQUIPMENT & NUMBER OF OBSERVATIONS / COMMON LOCATION \\
\hline 1 & $\begin{array}{l}\text { FIRE PROTECTION DEVICES ARE NOT PROPERLY } \\
\text { MAINTAINED }\end{array}$ & THE WHOLE MARKET \\
\hline 2 & FIRE PROTECTION DEVICES ARE NOT ADEQUATE & THE WHOLE MARKET \\
\hline 3 & $\begin{array}{l}\text { THERE IS NO SINGLE FIRE PROTECTION DEVICE IN ALL THE } \\
\text { LOCK-UP SHOPS AND THE OPEN STALLS }\end{array}$ & THE WHOLE OLD SECTION \\
\hline 4 & THE FIRE HOSE REELS ARE NOT IN GOOD CONDITION & 4 NUMBERS IN THE WESTERN PART OF THE NEW SECTION \\
\hline 5 & $\begin{array}{l}\text { USE OF SUBSTANDARD FIRE EXTINGUISHERS CAUSE RAPID } \\
\text { SPREAD OF FIRES }\end{array}$ & THE WHOLE MARKET \\
\hline 6 & $\begin{array}{l}\text { LOW SALARIES OF THE WORKERS IN CHARGE OF THE FIRE } \\
\text { EXTINGUISHERS }\end{array}$ & THE WHOLE MARKET \\
\hline 7 & $\begin{array}{l}\text { NO FRONT VERANDAHS OR CORRIDORS FOR MOUNTING } \\
\text { FIRE EXTINGUISHERS OR OTHER WALL MOUNTABLE FIRE } \\
\text { PROTECTION DEVICES }\end{array}$ & $\begin{array}{l}17 \text { BUILDINGS IN THE EASTERN AND CENTRAL PARTS OF } \\
\text { THE OLD SECTION }\end{array}$ \\
\hline 8 & $\begin{array}{l}\text { NO FIRE WARDEN PHONE IS MOUNTED ON THE WALLS OF } \\
\text { BUILDINGS }\end{array}$ & THE WHOLE MARKET \\
\hline
\end{tabular}

Source: Researchers' Field Work, 2017.

Fire protection devices must be located where they can be accessible for immediate uses to extinguish expected fires; an ideal market should be adequately protected against fire outbreaks, in order to save goods, properties and lives of people $[24,25,26]$. Yet, it was seen that fire protection devices are not adequate in Wuse market and therefore, the market is not adequately protected against fires. According to the management company of Wuse market, the old section of the market comprises of 1,365 lock-up shops and 500 open stalls. However, it was observed that there is no single fire protection device in the lock-up shops and open stalls in the whole old section of the market.

Strategically, fire hose reels are positioned at areas in buildings to give a reasonable amount of controlled and accessible supply of water for extinguishing fires [27]. Yet, it was seen that there are two buildings in the eastern and northern parts of the new section of the market without a single fire hose reel or any other fire protection device. However, other two buildings that are attached with a fire hose reel at the ground and first floor levels were found in the western part of the new section of the market but the focus group discussion with the sales people revealed that none of the fire hose reels is in good condition. In addition, the discussion with the Assistant Controller General of the FFSN revealed that the use of substandard fire extinguishers causes the fast spread of fire in Nigerian markets and it was stated that they have been observed in Wuse market. This is attributed to the issues of financial management that have yielded ineffective active fire preparedness in the market. The use of standard fire extinguishers in the market is necessary to stop the growth of fires at their early stages.

The discussion with the staff of the managing company of Wuse market indicated that the company has fire extinguishers; it was revealed that there is one portable extinguisher on the ground floor of the entrance hall of the management office building in the southern part of the old section of the market. Also, one portable fire extinguisher is kept at the entrance of the security post in the southern part of the old section of the market, and another one is kept at the police station in the southern part of the old section of the market. Similarly, the discussion with the staff of the management company of the market showed that there is a steel cage besides the management office building where four numbers of wheel type portable fire extinguishers are kept. Thus, the total summation of the fire extinghishers of the managing company of the market is seven.

The interview questions administered to the managing company of Wuse market revealed that there is a patrol team in the market which is made up of 25 trained persons. One of their duties is to move through the market to check minor fire outbreaks and to fight them with the fire extinguishers of the managing company of the market. This means that when fires are detected, the Market Patrol Team will have to quickly go to the management office where fire extinguishers are kept to carry them to the points of fire outbreaks to quench them. Hence, by this long process, there is a probability of fires to have done serious damages to the goods and properties of sales people before they can be tackled because there are sales points in the market that are more than 750 metres away from where the fire extinguishers of the management company are kept.

The interview questions administered to the managing company of Wuse market revealed that the salaries of the workers in the Market Patrol Team range from 20,000 Naira to 30,000 Naira; this is rather low and unsatisfactory. In any organisation, it is important that the workers are satisfied with their jobs, so that they can give the best of services under good working conditions [28,29]. In addition, it was observed that there are 17 buildings in the eastern and central parts of the old section of the market without front verandahs or corridors for mounting fire extinguishers or other wall mountable fire protection devices. Similarly, there is no building in the whole market with fire warden phones being mounted on its wall. In this case, there is a difficulty of informing the fire wardens about the fire outbreaks at the early stages of fires.

\subsection{Data from the Sales People}

In this subsection, active protection measures against fire were determined with respect to the issues associated 
with the firefighting equipment in the market based on the data from sales people. Concerning the levels of satisfaction with the fire fighting equipment, 145 (34.6\%) sales people responded that they are not satisfied with the firefighting equipment in the market. Conversely, 73 (17.4\%) sales people responded that they are averagely satisfied with the firefighting equipment in the market and three $(0.7 \%)$ sales people responded that they are very satisfied with the firefighting equipment in the market. $198(47.3 \%)$ sales people responded that there are no firefighting equipment in the market for any level of satisfaction to be derived. These statements affirmed that firefighting equipment are not adequate in the market by considering the levels of satisfaction of sales people. Figure 1 shows levels of satisfaction of sales people with firefighting equipment in the market.

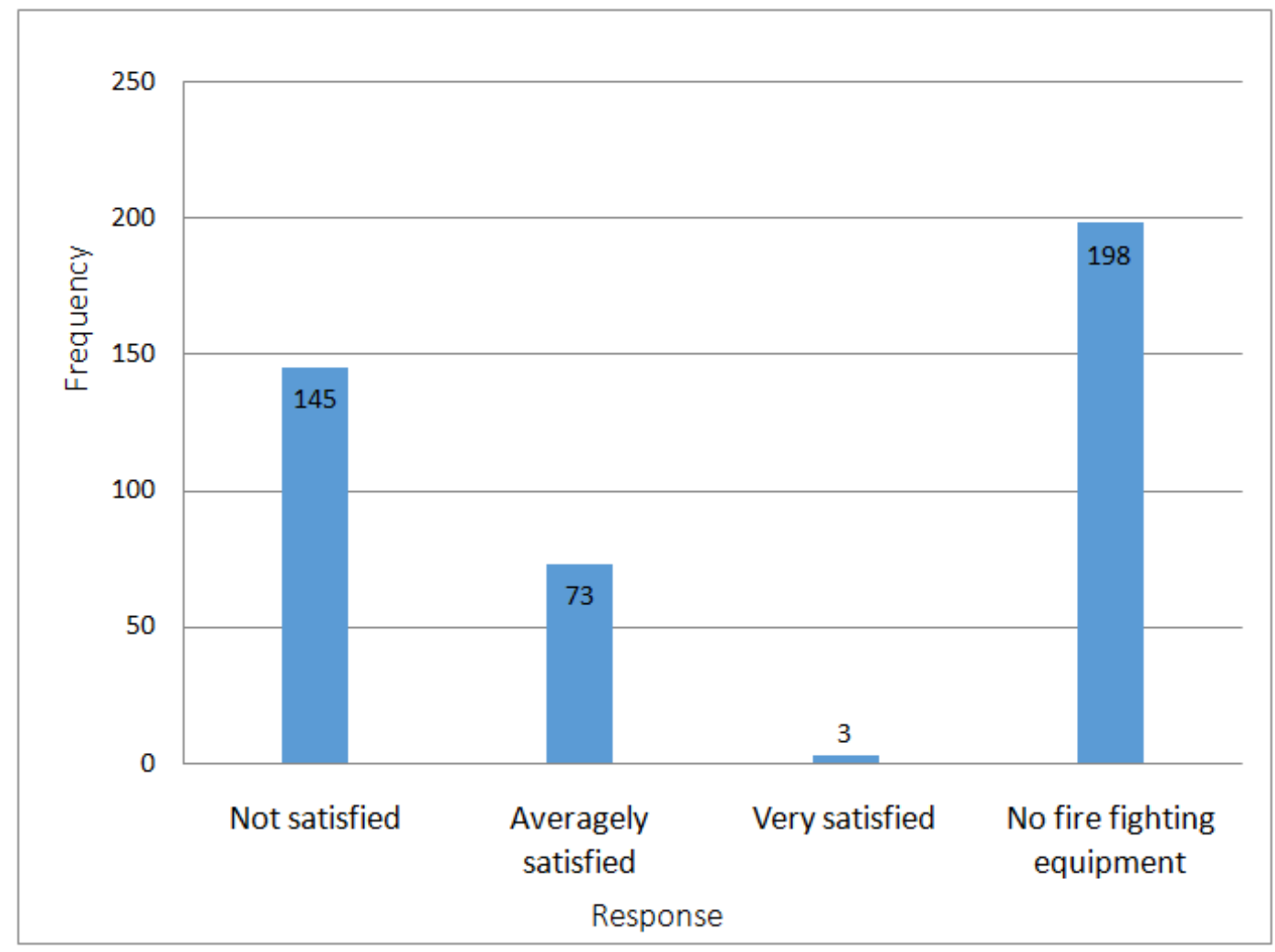

Figure 1. Levels of Satisfaction of Sales People with Fire Fighting Equipment in Wuse Market

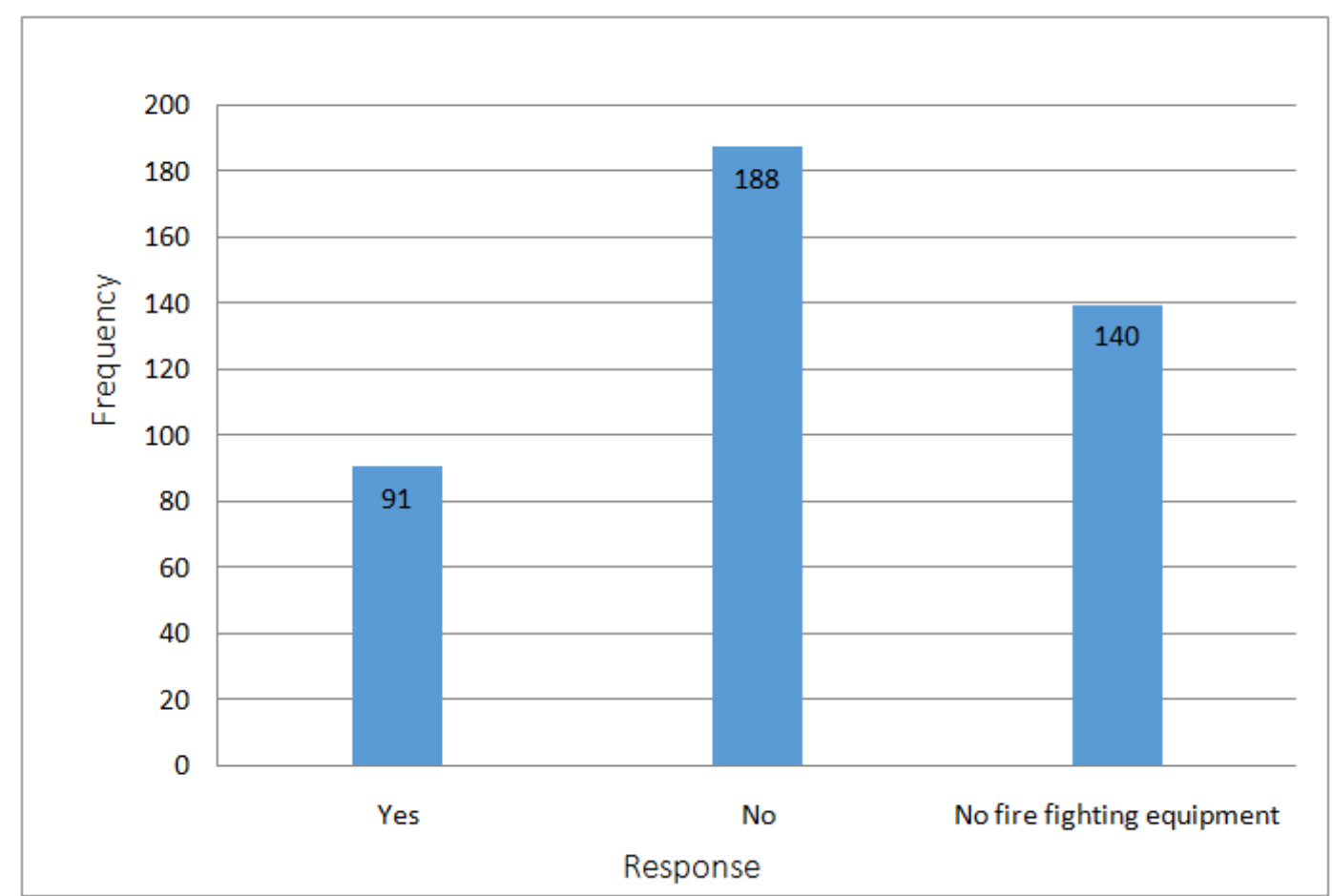

Figure 2. Responses of the Sales People in Wuse Market on how to Use Fire Fighting Equipment 
From the questionnaires administered to the Markets Operating Bodies such as Federal Fire Service of Nigeria (FFSN), National Association of Nigerian Traders (NANT) and the managing company of Wuse market, there are regular trainings for the sales people which are organised by the Markets Operating Bodies on how to use fire protection devices. The trainings range from every four months to two years. However, 188 (44.9\%) sales people in the market responded that they do not know how to operate firefighting equipment and 140 (33.4\%) sales people responded that there are no firefighting equipment in the market that will even encourage sales people to learn how to make use of them. $91(21.7 \%)$ sales people in the market responded that they know how to operate firefighting equipment. This immediate statement implies that the majority of sales people in the market do not know how to operate firefighting equipment and this is because most of them are not responding to calls for trainings on how to use them as affirmed from the discussion with the staff of the managing company of the market. Figure 2 shows responses of the sales people in the market on how to use firefighting equipment.

\section{Conclusion and Recommendations}

Having considered the problem of fire outbreaks in Nigerian markets in relation to the importance of markets as they contribute to the generation of local revenue, create employment, provide household incomes and support human resource development by providing for and educating the children or other family relatives of the sales people. Then, it became necessary that Wuse market is studied since it has experienced fire outbreak and it is located in the Federal Capital Territory (FCT) of Nigeria. The aim of the study was to determine the active protection measures against fire in the market, in order to generate guidelines that can reduce the occurrences of fire outbreaks in Nigerian markets.

The research findings are: fire protection devices in the market are not properly maintained; fire protection devices are not adequate in the market; the fire hose reels in the market are not in good condition; the use of substandard fire extinguishers in the market cause rapid spread of fires; the workers in charge of the fire extinguishers in the market are not well paid; there are buildings in the market without front verandahs or corridors for mounting fire extinguishers or other wall mountable fire protection devices; the majority of sales people in the market do not know how to operate firefighting equipment because most of them are not responding to calls for trainings on how to use them; Most of the sales people are not satisfied with the firefighting equipment in the market. Therefore, the following guidelines are recommended to reduce the occurrences of fire outbreaks in Nigerian markets:

i. The government of Nigeria should ensure that all the fire protection devices in markets should be properly maintained to an acceptable standard by the market management authorities. This will enable easy control of fires at the initial stages when there are fire outbreaks, in order to reduce the rate at which fires spread in the market buildings.
To achieve this, there should be regular inspection of the fire protection devices in markets by government representatives on yearly basis to ensure that they are regularly and well maintained via appropriate tests for their workability.

ii. The government of Nigeria must ensure the adequacy of fire protection devices in an acceptable standard at different strategic locations in markets, in order to effectively and efficiently reduce the rate at which fires spread.

iii. The management authorities of markets in Nigeria must ensure that fire protection devices (hose reels) in markets are in good condition at all times.

iv. The government of Nigeria should ban the use of substandard fire extinguishers in markets, so that when there are fire outbreaks, standard fire extinguishers can be used to easily control fires at the initial stages, in order to reduce the rate at which fires spread in market buildings. To achieve this, there should be regular inspection of the fire extinguishers in markets by government representatives on yearly basis with appropriate actions to minimise the rate at which people use substandard fire extinguishers.

v. The management authorities of markets in Nigeria should ensure that the well-trained market patrol teams for check mating the activities of the people that cause fires and for putting out fires by the use of fire protection devices are well paid. This will enable them to be satisfied with their jobs, in order to effectively and efficiently respond to duties or engage in proper disposal of their responsibilities.

vi. Floors of the lock-up shops in markets must be designed to have front verandahs/corridors and their inner walls should be appropriately used as the locations where the required fire warden phones, portable fire extinguishers, hose reels and other wall mountable fire protection devices shall be fixed upon.

vii. The management authorities of markets in Nigeria should enforce the mandatory training for all the sales people in markets on how to use fire protection devices, since most of them are not responding to calls for trainings on how to use them. This means that there should be enforcement of training for all the sales people in markets on protection measures against fire by any of the Markets Operating Bodies such as the market management authorities, Federal Fire Service of Nigeria, National Association of Nigerian Traders, and others with regular annual certificates of participation to be issued to them and such certificates of participation shall be subject to annual expiration, in order to yearly qualify the sales people to carry out business transactions in markets.

viii. All fire protection devices in markets must be up to the acceptable standard, so that all the sales people can be satisfied with them.

This research did not investigate the relationship between the existing fire protection devices and the expected classes of fires based on the different available 
materials that fuel fires in the market. This is a gap in knowledge, therefore, in subsequent research of this kind, this research gap should be filled.

\section{Acknowledgements}

Mega thanks go to the Almighty God for the enablement He granted us from the beginning to the end of this study. We acknowledge all the lecturers in the Federal University of Technology, Minna who have contributed to the success of this research. Profound thanks to the elder sister of the corresponding author and her husband who is presently late, Mrs. Umolaojo Angela Sani and Engineer Solomon Ayegba Sani, and the wife of the corresponding author Mrs. Ruth Ede Odaudu for the care, love and financial support throughout this research. We acknowledge the staff of the Federal Fire Service of Nigeria, National Association of Nigerian Traders, and the managing company of Wuse market who responded to our interview questions and the discussions of this research.

\section{References}

[1] Chabbi-Chemrouk, N, Koudougou central market, on site review report, Burkina Faso 2007 award cycle.

[2] Ngugi, G.P, Urban retail market transformation: A case of Gikomba market, Nairobi, Kenya, An unpublished thesis write-up, department of architecture and building science, university of Nairobi, 2015.

[3] Baah-Ennumh, T. Y. and Adom-Asamoah, G, The role of market women in the informal urban economy in Kumasi, Journal of science and technology, Ghana, 32(2), 56-67, 2012.

[4] Owusu, G. \& Lund, R, Markets and women's trade: exploring their role in district development in Ghana, Norwegian journal of geography, 58 (3), 113-124, 2004.

[5] Ejeta, L.T., Ardalan, A. and Paton, D, Application of behavioral theories to disaster and emergency health preparedness: a systematic review, Currents disasters of PLOS Journal, 2015. Available: http://currents.plos.org/disasters/article/application-ofbehavioral-theories-to-disaster-and-emergency-healthpreparedness-a-systematic-review/.

[6] Paton, D, Disaster preparedness: a social cognitive perspective, International journal of disaster prevention and management, 12(3), 210-216, 2003.

[7] Mathbor, G.M, Enhancement of community preparedness for natural disasters: the role of social work in building social capital for sustainable disaster relief and management, International social work, 50 (3), 357-369, 2007.

[8] Menon, G.B. and Vakil, J.N, Handbook on building fire codes, Final report c fire codes, 2016. Available: http://www.iitk.ac.in/nicee/IITK-GSDMA/F05.pdf.

[9] Federal Fire Service of Nigeria, Market fires killed 600 in 15 months, the controller general (Joseph Anebi), federal fire service of Nigeria, 2016. Available: http://punchng.com/market-fire-killed-600-in-15-months-cg/.

[10] Federal Fire Service of Nigeria, Checking fire disaster in Abuja, tag of the federal fire service of Nigeria by all Africa news and information, 2003. Available: allafrica.com/stories/200301220770.html

[11] Federal Fire Service of Nigeria, Fire outbreak at Ilesa major market, Ilesa, Osun State, Nigeria, official facebook website of the federal fire service of Nigeria, 2015. Available:
https://web.facebook.com/FEDERALFIRESERVICEPRESS/phot os?ref=page internal.

[12] Pinterest Map Data, Location of Wuse Market, A map showing the location of Wuse market, 2018. Available: https://www.pinterest.com/pin/293930313162114274/.

[13] Nnodim, N.J, Center for performing arts, Abuja: a study of the methods for improving accessibility and increasing participation of people with disabilities, a master degree thesis, department of architecture faculty of environmental studies university of Nigeria, Nsukka, Enugu State, Nigeria, 2011.

[14] Federal Capital Development Authority of Nigeria, The department of urban and regional planning, builders of Abuja, 2016. Available:

http://fcda.gov.ng/index.php?option=com content\&view $=$ article \& $\mathrm{id}=30 \&$ Itemid $=66$.

[15] Abuja Markets Management Limited, Our Facilities, 2016. Available: http://www.abujamarketsmanagement.com/our-facilities/.

[16] Prashant K. and Supriya B, Sample size calculation, International journal of ayurveda research, 1(1), 55-57, 2010.

[17] Steve, C, What is the smallest sample size i can use for my study? The dissertation statistics consultant blog, 2011. Available: http://www.statisticsconsultant.com/dissertation-advice/what-isthe-smallest-sample-size-i-can-use-for-my-study/.

[18] Suresh, K.P. and Chandrashekara, S, Sample size estimation and power analysis for clinical research studies, Journal of Human Reproductive Sciences, 5(1), 7-13, 2012.

[19] Masadeh, M.A, Focus group: reviews and practices, International journal of applied science and technology, 2(10), 63-68, 2012.

[20] Morgan, M., Gibbs, S., Maxwell, K. and Britten, N, Hearing children's voices: methodological issues in conducting focus groups with children aged 7-11 years, Sage Publication, Thousand Oaks, 2002.

[21] National Fire Protection Association, Portable fire extinguisher inspection and maintenance schedule, a schedule of the inspection and maintenance of portable fire extinguisher as referenced by the Connecticut State fire safety code, 1998. Available: http://www.pbfd.net/Forms\%20and\%20Information/Forms\%20an d\%20Information_files/Fire\%20Extinguisher\%20Inspection $\% 20 \mathrm{~S}$ chedule.pdf.

[22] Fire Protec, How often should fire extinguishers be inspected? Fire inspection blog, Fire protect company, 2016. Available: https://resources.fireprotec.com/how-often-should-fireextinguishers-be-inspected.

[23] Marsden Fire Safety, Fire extinguisher servicing, a guide for fire extinguisher servicing, Marsden fire safety limited, 2018. Available: https://www.marsden-fire-safety.co.uk/resources/fireextinguishers/fire-extinguisher-servicing.

[24] Access Intelligence, Fire protection options for air-cooled hydroelectric generators, a report of business and technology for the global generation industry, 2016. Available: http://www.powermag.com/fire-protection-options-for-air-cooledhydroelectric-generators/.

[25] Leo, M. T, An assessment of the awareness of fire insurance in the informal sector: a case study of Kumasi central market in Ghana, International journal of humanities social sciences and education (IJHSSE), 1(8), 41-47, 2014.

[26] Oladokun, V.O. and Emmanuel, C.G, Urban market fire disasters management in Nigeria: a damage minimization based fuzzy logic model approach, International journal of computer applications, 106(17), 0975-8887, 2014.

[27] Grundfos, Fire hose reel system, Manufacturer of hose reel, Denmark, 2016. Available: http://www.grundfos.com/service/encyclopedia-search/fire-hosereel-systems.html.

[28] Dobre, O, Employee motivation and organisational performance, Review of applied socio-economic research, 5(1), 53, 2013.

[29] Sageer, A., Rafat, S. and Agarwal, P, Identification of variables affecting employee satisfaction and their impact on the organization. IOSR journal of business and management, 5(1), $32-39,2012$. 